\title{
Hungarian Food Consumers' Preferences, from the Aspect of Ethnocentrism
}

\author{
Mónika Garai-Fodor'1, Anett Popovics² \\ Keleti Károly Faculty of Business and Management, Óbuda University \\ 1fodor.monika@kgk.uni-obuda.hu; ORCID: 1 0000-0001-7993-2780 \\ 2popovics.anett@kgk.uni-obuda.hu; ORCID: 20000-0003-3050-6953
}

\begin{abstract}
This paper highlights ethnocentric food consumption or the favoring of domestically produced food products. One of the theoretical pillars of the study is the trend toward ethnocentrism. Several studies proved that consumers are more positive about products from their own region. We would like to examine the Hungarians' opinion concerning their own products within the Hungarian food market. The other pillars of the theoretical background of the study are general food consumer behavior models and theories within the frame, of which, we analyzed the most important changes of the mindset of food consumers and the main structural diversion of food preferences. In the primary research, quantitative strategy, has been used, with the help of a pre-tested standardized questionnaire and snowball sample taking methods, 1447 questionnaires were evaluated. These research tools typically include closed-ended questions: selective, combinative semantic differential scales and ranking in the form of question types. The main aim of the research was to analyze the Hungarian consumers' preferences, for case of food consumption and characterize the most important target markets of the Hungarian food industry. We examined the attitude of the respondents toward Hungarian foods, from affective, cognitive and conative aspects. We also investigated the general food-consumer preferences of our respondents and the main elements of preference for Hungarian food consumption. As a result, we could characterize the most important features that Hungarian food-consumers associate with Hungarian food, we could also understand the advantages and disadvantages of various Hungarian foods. In addition, we could distinguish food consumer patterns, based on food consumption preferences. The results of this work can serve as an orientation for the players in the Hungarian food markets, to characterize their potential target markets and access the most important consumer groups, for the case of Hungarian food promotion.
\end{abstract}

Keywords: food consumption; preferences; ethnocentrism 


\section{Introduction}

Food consumer behavior is a part of the human behavior spectrum. A variety of cultural, psychographic and personal factors affect the consumer's, final decision. As a result, in several cases, it is important to use a multidisciplinary approach when studying consumer behavior, so we can understand and explore the system of correlations that underlie consumer decision-making only by considering these variables together. Ethnocentricism, which serves as the study's theoretical foundation, is a term that can be explained in a variety of ways, including cultural, emotional and/or value system differences. We aim to briefly summarize these theories and present their connection points, supplementing it with generation specific consumer behavior characteristics.

\subsection{Consumer Behavior of Hungarian Foods}

Based on the literature, we can examine the consumer behavior of Hungarian foods on two levels. On the one hand, our image of the given product or brand is influenced by the country of origin, the "country-of-origin" image, a part of the image of a product, which is based on the origin of the product in a given country. On the other hand, research proves that the role of regional origin can be demonstrated on the levels of the purchasing decision process.

The factor related to the concept of country of origin image is the so-called consumer ethnocentrism, according to which ethnocentric consumers rely more on country-of-origin information, consider purchasing products from abroad incorrect because it endangers the domestic economy while non-ethnocentric consumers judge both domestic and foreign products on the basis of its quality. This effect is the strongest in the case of food purchases as consumers also develop a kind of nostalgia-based emotional attachment to Hungarian food brands (e.g. Túró Rudi) and, based on tradition, these products are also attributed to good quality [1].

According to the research of Verlegh and Steenkamp [2], if the consumer is confident enough that the origin of the product, the country of origin, guarantees good quality, then this factor demonstrably participates in the evaluation of the product. Otherwise, the consumer evaluates the product features one by one before making a purchase decision.

Although consumer ethnocentrism itself, belongs to the field of social psychology, its marketing-oriented consumer approach, has also provided the basis for a number of studies. Several consumer behavior surveys have shown that ethnocentrism influences purchasing decisions, affects both product evaluation and buying intentions $[3,4]$. The consecutive ethnocentrism studies looked at buying intent and attitudes [5, 6]. 
It is essential to emphasize that both economic growth and consumer welfare have an effect on ethnocentrism $[3,7]$.

Consumers in economically developed countries have a higher level of confidence in goods made in their own country, so ethnocentrism is stronger while consumers in less developed countries have a much lower level of confidence in products made in their own country [8].

To understand consumers' motivations, they need to know their goals and knowledge of a particular product, as well as their attitudes, which together influence the decision-making process.

Some of the researches $[9,10]$ show that consumers have a more positive attitude towards products from their own region. The likelihood that a regional product will be included in the purchasing decision process depends to a large extent on how the consumer identifies it in the information gathering phase. Information about a regional product can be retrieved from memory when a purchasing problem occurs (internal information retrieval) or when the consumer encounters the product during the information retrieval phase (external information retrieval). Ittersum [9] found that consumers are interested in the region, information about the region, and therefore the increasing interest may enhance the likelihood of encountering the regional product. The perception of regional products is also related to culture: the more consumers are attracted to the culture of a given region, the more positive they are to regional products.

According to Chaney's [11] lifestyle model, food consumption is part of sociocultural status, so food and drink are also indicators of taste, fashion, and demandingness among lifestyle traits. Regional foods also evoke nostalgia for the past when consumers were even younger or when they left, they spent his holiday in pleasant company. Especially people living in the city can evoke nostalgia for traditional flavors for rural holidays and rural pastimes. Local products re-evaluate the individual's cultural identity, these values and symbols contribute to the relocalization of culture [12].

The final conclusions of a series of Hungarian research were in line with the international findings. Hungarian products were normally devalued in Hungary at the time of the regime change, as opposed to those from Western countries [13, 14].

Berács and Malota [15] found that Hungarian respondents were generally positive about domestic products ten years later, but that the perception of products from developed countries was still more favorable.

Szakály et al. $[10,16]$ analyzed consumer habits and attitudes in the traditional Hungarian food market. Based on the results of the research, consumers understand the term traditional Hungarian food to be prepared only with Hungarian-flavored dishes prepared on the basis of an old recipe. 97\% of the respondents consume some traditional Hungarian food, those who do not, they do 
not buy the products due to the high price. The consumption of traditional foods is influenced by the taste and constant quality associated with the product, family preference and the quality guarantee brand. Further research has proved that the consumption of Hungarian food is part of everyday meal and cannot be linked to a specific festive or special occasion. People over the age of 40, one- and twoperson households, and southern Hungarians are more likely to consume traditional foods.

In terms of food quality, it has also been shown that the quality of traditional foods is valued higher by consumers than by foreign products. More than $40 \%$ of the respondents think that the quality of Hungarian food is better than that of foreigners, and more than $80 \%$ of the respondents consider the average quality of traditional food to be good or excellent [17].

Median's [18] research has shown that Hungarian consumers make food choices based on the following order of importance: price, quality, health, Hungarian origin.

\subsection{Generational Peculiarities in Consumer Behavior}

The second literature pillar of our study is generation marketing.

As in our primary research we focused on the differences in food consumption due to age, we had to make a short overview of the most important features of Generation $\mathrm{Z}$ and $\mathrm{Y}$, which were overrepresented, in our sample.

The values and ways of thinking of Generation $\mathrm{Y}$ and $\mathrm{Z}$ are characteristic only of them and different from the previous generations. Their consumer behavior and financial decisions can be influenced by the application of the appropriate communication strategy [19].

Töröcsik [20] examined the generational differences in food shopping in primary research, and found that young women shop with great enthusiasm and impulse, but store loyalty does not characterize them. Young men prefer to shop online rather than shopping in real life. Female members of the middle-aged generation either buy food with an action-sensitive, emotional charge, or in a functional, fast, goal-oriented way.

Examining the consumer habits of the $\mathrm{Y}$ generation, it can be said that compared to the previous generation, they have already grown up in the consumer society, all products have become available to them, they do not know the concept of a "shortage item". The motivations of their consumer habits move on several levels: on the one hand, they look for novelties, new experiences and are characterized by impulse buying. On the other hand, brand loyalty is not typical of them, they do not necessarily buy the most expensive, prestigious product. They prefer personalized options, comfort and flexibility in their decisions. Environmental awareness and social responsibility are also very important to them [21]. 
Based on the research of Varga [22] the offline purchasing decision of Generation $\mathrm{Z}$ is greatly influenced by the experience gained in the store. If they are attentive, they are kind in the store with them, if they feel they are an important customer, they value it more than gifts. The most popular and influential promotional tool is the discount but the need for entertainment, the shopping experience strongly influences the product choice of young people.

Generation $\mathrm{Z}$ has a strong purchasing power, but compared to members of Generation $\mathrm{Y}$, the relationship with their parents is stronger, so their purchasing decisions are often made with them [23].

\section{Method}

In this study, in addition to the systematic processing of relevant domestic and international literature, we present the partial results of our primary research. We conducted quantitative research in the framework of primary data collection in the form of a pre-tested, standardized online questionnaire.

Subjects were recruited using a snowball sampling procedure, which resulted in 1447 questionnaires.

The research tool included only closed-ended questions, nominal measurement levels, single- and multiple-choice selective questions, Likert scale and a semantic differential scale to analyze consumer attitudes and values. Scale questions used a scale from 1 to 4 . The reason for this is, on the one hand, the individual scale preference, which is typical of Hungarian respondents: due to the school classification system, our Hungarian respondents can interpret the scale up to five grades most stably against the 1-7, 1-9 or 1-10 scales.

We chose the even scale because in the case of the odd (1-5) scale, the mean value (3) is a kind of escape route, for the respondents. In the analysis of the attitude, in the case of those who choose the average value, the balance does not tilt in either direction, resulting in an excessive proportion of "indifferent" consumers, thus making it difficult to statistically and professionally evaluate segmentation [24]. Therefore, we opted for the even scale, which, by excluding the mean value, forces the respondent to take a more definitive position, thus better contributing to the successful segmentation. In addition, for the questions analyzed using the odd scale, it was not necessary for the mean, indifferent value to give either the "I don't know" choice, because the cognitive level was filtered using separate questions.

The development of the topics of the research tool was realized as a result of the relevant secondary data analysis. Each response alternative was finalized - pretested of the research tool - in the light of qualitative results. As part of this 
qualitative research phase, we conducted 10 mini-focus group interviews using a semi-structured interview outline. Qualitative sampling was also performed using the snowball method. The mini-focuses were group-directed conversations with a heterogeneous composition in terms of gender and age, with the participation of 3-4 people each. The main goal of the qualitative research was to establish the quantitative research, finalize the standardized questionnaire and outline the research hypotheses.

The topics of the quantitative research tool finalized as a result of the qualitative phase were the following: food buying habits, food consumption preferences, Hungarian food buying habits and domestic food consumption preference, assessment of Hungarian food (cognitive, affective and conative phase), sociodemographic data.

In the present study, we focus on the partial results of the quantitative phase of our research project. Within that, we also gave priority to food purchasing habits, possible segmentation opportunities based on preference, and the relationship of each food shopping segment to Hungarian food.

In the framework of quantitative research, we formulated one main and two subhypotheses. These are based on food consumer behavior theories [25, 26], that explain the buyer's decision, ethnocentric consumer behavior in the context of values $[27,28,29]$. What these concepts have in common is that an individual's consumer and consumer decision is interpreted as an external projection of their value system. [30, 31]. These hypotheses are:

(H1) There is a correlation between food customer preferences and attitudes towards Hungarian food.

(H1/a) Distinct consumer groups can be defined according to food consumer preferences

(H1/b) There is a statistically verifiable correlation between the segments formed according to the preferences of certain food buyers and the attitude towards Hungarian food.

In order to process the quantitative results and test the hypotheses, we used descriptive statistics, bivariate analyzes using SPSS 22.0 software. In case of the bivariate analyzes significance and $\mathrm{F}$ values were considered in the correlations examined by analysis of variance. In the case of Chi-square analyses, each relationship was subject to an internal correlation analysis based on the values of the corrected standardized residues (AdjR), which were interpreted as follows: Adj.R $>=2$ indicates a positive deviation from the expected value with a $95 \%$ confidence level; Adj.R $>=3$ indicates a positive deviation from the expected value with a $95 \%$ confidence level. In the case of a negative sign, the deviation from the expected value is negative at these value intervals [32]. 


\section{Findings}

\subsection{Sociodemographic Characteristics of the Sample}

$60 \%$ of the respondents were women and $40 \%$ were men.

By age, 16-20 year olds had the highest proportion of respondents (31.1\%), followed by young people aged 21-25 years. $(24.5 \%)$. That is, more than half of the sample $(55.5 \%)$ were respondents younger than 25 years, i.e., a member of Generation Z.

Unsurprisingly, in terms of age, $42 \%$ of respondents are single and $54 \%$ are married or in a cohabiting relationship. $42 \%$ of the respondents are residents of the capital, $38 \%$ live in cities and only $20 \%$ are residents of villages. In terms of educational attainment, those with secondary qualifications were absolutely overrepresented $(70 \%)$.

\subsection{Food Shopping Habits}

First, we examined the food buying habits of the respondents.

Sample members typically (32.8\%) buy food themselves, and not surprisingly, the second most populous group $(28.4 \%)$ who buy food with their parents in relation to the over-represented young target audience.

Table 1

Sample distribution by food purchasers

\begin{tabular}{|l|c|}
\hline \multicolumn{1}{|c|}{ Those who buy food } & $\begin{array}{c}\text { Relative frequency \% (several } \\
\text { answers could be accepted) }\end{array}$ \\
\hline Especially me & 32.8 \\
\hline Typically my parents & 28.4 \\
\hline Most of the time my spouse / partner & 6.3 \\
\hline Typically me with my parents & 12.2 \\
\hline Specialty shop & 20.3 \\
\hline Especially me with my spouse / partner & 32.8 \\
\hline
\end{tabular}

Source: authors' own research, $2020 \mathrm{~N}=1447$

$43.3 \%$ of respondents $27.3 \%$ buy food several times a week and $26.2 \%$ buy food twice a week.

The largest share (30.6\%) was made up of those who spend between HUF 21,000 and HUF 30,000 on food on a monthly basis. The second most populous group of respondents (26.9\%) spend between HUF 10,000 and HUF 20,000 for food. 
The results show that respondents prefer discounts when buying food, and buy food at a specialty store the least.

Table 2

Food shopping locations in the sample

\begin{tabular}{|l|c|c|}
\hline \multicolumn{1}{|c|}{ Type of market } & Average (1= most often) & Standard deviation \\
\hline Hypermarket & 2.33 & 1.09 \\
\hline Supermarket & 2.20 & 1.04 \\
\hline Discount & 1.85 & 0.95 \\
\hline Convince store & 2.68 & 1.09 \\
\hline Specialty shop & 3.38 & 0.94 \\
\hline Traditional market & 2.90 & 1.04 \\
\hline
\end{tabular}

Source: authors' own research, $2020 \mathrm{~N}=1447$

The system of food preference was also examined separately. Based on the results, we observed the absolute dominance of comfort aspects, which, in our view is largely related to the fact that the majority of the sample members were young consumers under 25 years of age.

The durability, content value and easy accessibility of the food were the main aspects in the consumer preference system. The cheapness of food has also been relegated to the background in relation to these aspects. Given that discounts were preferred by subjects among the places where food is purchased, it can be assumed that the role of price already dominates in business choice and therefore additional considerations come to the forefront, in the case of product preference.

Table 3

Food purchase preference system in the sample

\begin{tabular}{|c|c|c|}
\hline Aspects of food purchasing & $\begin{array}{c}\text { Average (where 1 = } \\
\text { not important all, } \\
4=\text { most important) }\end{array}$ & $\begin{array}{c}\text { Standard } \\
\text { deviation }\end{array}$ \\
\hline Content values (taste, smell, calorie content) & $\mathbf{2 . 8 4}$ & 1.02 \\
\hline Geographical origin (place of origin of the food) & 2.26 & 0.98 \\
\hline Food must be cheap & $\mathbf{2 . 5 0}$ & 0.92 \\
\hline Food must be on sale & 2.34 & 0.93 \\
\hline Attractiveness of packaging & 2.04 & 0.90 \\
\hline Food made exclusively from Hungarian ingredients & 2.18 & 0.95 \\
\hline Brand & 2.34 & 0.94 \\
\hline Practicality of packaging & 2.22 & 0.90 \\
\hline Food durability, shelf life & $\mathbf{3 . 0 6}$ & 0.96 \\
\hline Have a trademark on the packaging & 2.25 & 1.00 \\
\hline Be easily accessible & $\mathbf{2 . 6 9}$ & 1.00 \\
\hline Food advertising & 1.75 & 0.86 \\
\hline
\end{tabular}

Source: authors' own research, $2020 \mathrm{~N}=1447$ 
In terms of food shopping habits, overall, the majority of respondents buy food themselves, and prefer discounts. On a monthly basis, most respondents spend between HUF 21,000 and HUF 30,000 on food, the durability, content values and easy availability, are the main aspects in their selection, pushing the criterion of cheapness into the background.

\subsection{Buying and Judging Hungarian Food}

In the case of Hungarian foods, we also examined the criteria of food purchase separately, considering that our hypothesis $\mathrm{H} 1$ shows a difference compared to the normal food purchase preference. According to the results, the preference system for Hungarian foods has changed slightly: in the first place in this case, as well although with a lower average value - the durability of the food came. In the case of Hungarian foods, the importance of the content values is more dominant compared to the general food purchase preference system, as well as the fact that it is made exclusively from Hungarian ingredients. Our respondents also pay more attention to the geographical origin when buying Hungarian food, but the cheapness of food is pushed into the background when buying Hungarian food compared to general food.

Table 4

Consumer preference for Hungarian foods

\begin{tabular}{|l|c|c|c|c|}
\hline \multicolumn{1}{|c|}{$\begin{array}{c}\text { Aspects of } \\
\text { purchasing }\end{array}$} & \multicolumn{2}{|c|}{ Aspects of food purchasing } & \multicolumn{2}{c|}{$\begin{array}{c}\text { Aspects of Hungarian food } \\
\text { purchasing }\end{array}$} \\
\cline { 2 - 5 } & $\begin{array}{c}\text { Average (where 1 } \\
\text { not important at all, } \\
4=\text { most important) }\end{array}$ & $\begin{array}{c}\text { Standard } \\
\text { deviation }\end{array}$ & $\begin{array}{c}\text { Average (where 1 = } \\
\text { not important at all, } \\
4=\text { most important) }\end{array}$ & $\begin{array}{c}\text { Standard } \\
\text { deviation }\end{array}$ \\
\hline $\begin{array}{l}\text { Content values } \\
\text { taste, smell, } \\
\text { calorie content, }\end{array}$ & $\mathbf{2 . 8 4}$ & 1.02 & $\mathbf{2 . 9 4}$ & 1.09 \\
\hline $\begin{array}{l}\text { Geographical } \\
\text { origin (place of } \\
\text { origin of the food }\end{array}$ & 2.26 & 0.98 & $\mathbf{2 . 5 1}$ & 1.05 \\
\hline $\begin{array}{l}\text { Food must be } \\
\text { cheap }\end{array}$ & $\mathbf{2 . 5 0}$ & 0.92 & 2.40 & 0.97 \\
\hline $\begin{array}{l}\text { Food must be on } \\
\text { sale }\end{array}$ & 2.34 & 0.93 & 2.27 & 0.97 \\
\hline $\begin{array}{l}\text { Attractiveness of } \\
\text { packaging }\end{array}$ & 2.04 & 0.90 & 2.01 & 0.89 \\
\hline $\begin{array}{l}\text { Food made } \\
\text { exclusively from } \\
\text { Hungarian } \\
\text { ingredients }\end{array}$ & 2.18 & 0.95 & 2.74 & 0.96 \\
\hline Brand & 2.34 & 0.94 & 2.35 & 0.90 \\
\hline $\begin{array}{l}\text { Practicality of } \\
\text { packaging }\end{array}$ & 2.22 & 0.90 & 2 \\
\hline
\end{tabular}




\begin{tabular}{|l|c|c|c|c|}
\cline { 2 - 5 } $\begin{array}{l}\text { Food durability, } \\
\text { shelf life }\end{array}$ & $\mathbf{3 . 0 6}$ & 0.96 & $\mathbf{3 . 0 0}$ & 0.98 \\
\hline $\begin{array}{l}\text { Have a trademark on } \\
\text { the packaging }\end{array}$ & 2.25 & 1.00 & 2.25 & 0.97 \\
\hline Be easily accessible & $\mathbf{2 . 6 9}$ & 1.00 & $\mathbf{2 . 6 4}$ & 1.01 \\
\hline Food advertising & 1.75 & 0.86 & 1.69 & 0.83 \\
\hline
\end{tabular}

Source: authors' own research, $2020 \mathrm{~N}=1447$

In terms of the frequency of Hungarian food purchases, it surpasses normal food among the respondents: $47.5 \%$ of the respondents buy Hungarian food every day, $36 \%$ several times a week. According to the sample members, on average $30.33 \%$ of the food they buy is Hungarian food, which, in our opinion represents a rather large proportion.

We analyzed the opinions of the samples regarding Hungarian food, we were interested in how Hungarian food is perceived by consumers compared to normal food. According to the results, a significant part of the respondents (40.2\%) do not perceive a difference in quality between Hungarian and normal food. However, there were a significant number $(39.5 \%)$ who said that the quality of Hungarian food was better.

Table 5

Judging the quality of Hungarian food

\begin{tabular}{|l|c|}
\hline $\begin{array}{l}\text { The quality of Hungarian food compared } \\
\text { to normal food }\end{array}$ & Frequency $(\boldsymbol{\%})$ \\
\hline Right & $\mathbf{3 9 . 5}$ \\
\hline Worse & 5.7 \\
\hline Same & $\mathbf{4 0 . 2}$ \\
\hline I do not know & 14.7 \\
\hline & $\mathbf{1 0 0 . 0}$ \\
\hline
\end{tabular}

Source: authors' own research, $2020 \mathrm{~N}=1447$

Regarding the reliability of Hungarian food, we obtained a similar value: the highest proportion was formed by the respondents who think that the reliability of normal and Hungarian food is the same. In this case, however, the range of those for whom Hungarian food is better was also significant in the case of reliability.

Table 6

Assessing the reliability of Hungarian food

\begin{tabular}{|l|c|}
\hline $\begin{array}{l}\text { Reliability of Hungarian food compared to } \\
\text { normal food }\end{array}$ & Frequency (\%) \\
\hline Right & $\mathbf{3 7 . 5}$ \\
\hline Worse & 5.2 \\
\hline Same & $\mathbf{4 4 . 0}$ \\
\hline I do not know & 13.3 \\
\hline \multicolumn{2}{|c|}{ TOTAL } \\
\hline
\end{tabular}

Source: authors' own research, $2020 \mathrm{~N}=1447$ 
Based on the affective component of the attitude towards Hungarian food, we could see that the vast majority of the sample is happy to buy Hungarian food because it supports domestic jobs.

Table 7

Judging Hungarian food

\begin{tabular}{|l|c|}
\hline \multicolumn{1}{|c|}{$\begin{array}{c}\text { I like to buy Hungarian food because with this I support } \\
\text { Hungarian jobs }\end{array}$} & Frequency (\%) \\
\hline Yes & 75.3 \\
\hline No & 27.7 \\
\hline The price of Hungarian food compared to normal food & Frequency (\%) \\
\hline Higher & 44.3 \\
\hline Lower & 13.4 \\
\hline Same & 28.7 \\
\hline I do not know Altogether & 13.5 \\
\hline & $\mathbf{1 0 0 . 0}$ \\
\hline I only buy Hungarian food if it is cheaper than normal food & Frequency (\%) \\
\hline Yes & 25.2 \\
\hline No & 74.8 \\
\hline \multicolumn{1}{r}{ TOTAL } & $\mathbf{1 0 0 . 0}$ \\
\hline
\end{tabular}

Source: authors' own research, $2020 \mathrm{~N}=1447$

The price of Hungarian food was considered high by a significant part of the sample.

In comparison, it is not even typical for the sample to buy Hungarian food at a special / cheaper price. Based on these answers, that is the reason, not the price or the price discount in the case of Hungarian food.

In the light of the results, it is also not typical for our respondents to buy Hungarian food out of fashion or to follow the behavior of their parents or friends.

Table 8

Motives of buying Hungarian food

\begin{tabular}{|l|c|c|}
\hline \multirow{2}{*}{ Motives } & \multicolumn{2}{c|}{ Frequency (\%) } \\
\cline { 2 - 3 } & Yes & No \\
\hline I buy Hungarian food because it is fashionable and trendy & 3.3 & $\mathbf{9 6 . 7}$ \\
\hline I buy Hungarian food because my parents buy it, too & $\mathbf{2 0 . 7}$ & 79.3 \\
\hline I buy Hungarian food because my friends buy it ,too & $\mathbf{9 . 5}$ & 90.5 \\
\hline
\end{tabular}

Source: authors' own research, $2020 \mathrm{~N}=1447$ 


\subsection{Purchase and Assessment of Hungarian Food as a Factor of Age}

In order to test our hypothesis $\mathrm{H} 2$, we analyzed whether there is correlation between age and the extent of Hungarian food purchases. According to the results of the variance analysis $(\mathrm{sig}=0.000)$ there is a statistically verifiable correlation between the two variables. Based on the values of the ANOVA table, it can be seen that the proportion of Hungarian foods purchased monthly increases with age.

Table 9

Proportion of Hungarian foods within the monthly level of food purchased (average)

\begin{tabular}{|c|c|c|}
\hline Age groups & N (person) & $\begin{array}{c}\text { Proportion of Hungarian foods within the } \\
\text { monthly level of food purchased (average) }\end{array}$ \\
\hline $\mathbf{1 6 - 2 0}$ year & 417 & 26.48 \\
\hline $\mathbf{2 1 - 2 5}$ year & 333 & 25.61 \\
\hline $\mathbf{2 6 - 3 0}$ year & 88 & 26.73 \\
\hline 31-35 year & 58 & 34.58 \\
\hline 36-40 year & 182 & 34.14 \\
\hline over 45 year & 230 & 41.24 \\
\hline
\end{tabular}

Source: authors' own research, $2020 \mathrm{~N}=1447$

In the course of the research, we also examined whether there is a correlation between the age of the respondents and the perception of Hungarian food. For this, we performed a Chi-square test, during which, the correlation could be detected based on Pearson's significance value $(\mathrm{sig}=0.000)$. The corrected standardized residual (Adj.R) was used to analyze the internal correlations. In light of this, we could state that the proportion of respondents under the age of 25, i.e. Generation Z, was lower than expected or than those who rated the quality of Hungarian food as being better. However, among the respondents older than 36 years, i.e. belonging to Generation X, a larger proportion of respondents consider the quality of Hungarian food to be better than expected. Among those who considered the quality of Hungarian food to be the same, the proportion of young people was higher than the expected value and that of the older generation was lower. The same relationship is true for uncertain subjects ("don't know" answers).

According to the results of the research, we were able to establish a statistically verifiable correlation between age and the assessment of the reliability of Hungarian food ( $\mathrm{sig}=0.000$ ). Based on the results, among the members of the older generation over the age of 45, those who considered Hungarian food to be more reliable were present in a higher percentage than expected, while in the case of young people (aged 16-20) they showed a smaller proportion than expected. In this case, too, the proportion of young people who considered the reliability of Hungarian food to be the same as normal food was higher than expected, and the proportion of young people over 45 was lower. 
Table 10

Judging the quality of Hungarian food as a function of age

\begin{tabular}{|c|c|c|c|c|c|c|c|c|}
\hline \multirow{2}{*}{\multicolumn{2}{|c|}{$\begin{array}{l}\text { The quality of } \\
\text { Hungarian food } \\
\text { compared to } \\
\text { normal food }\end{array}$}} & \multicolumn{6}{|c|}{ Age groups } & \multirow[b]{2}{*}{$\begin{array}{c}\text { SUM } \\
(\%)\end{array}$} \\
\hline & & $\begin{array}{l}16-20 \\
\text { year }\end{array}$ & $\begin{array}{l}21-25 \\
\text { year }\end{array}$ & $\begin{array}{l}26-30 \\
\text { year }\end{array}$ & $\begin{array}{l}\text { 31-35 } \\
\text { year }\end{array}$ & $\begin{array}{l}36-40 \\
\text { year }\end{array}$ & $\begin{array}{c}\text { over } \\
45 \\
\text { year }\end{array}$ & \\
\hline \multirow{3}{*}{ Better } & row $\%$ & $21.8 \%$ & $20.0 \%$ & $7.6 \%$ & $4.4 \%$ & $17.2 \%$ & $28.9 \%$ & $100.0 \%$ \\
\hline & column \% & $27.6 \%$ & $32.3 \%$ & $43.0 \%$ & $41.0 \%$ & $47.3 \%$ & $60.4 \%$ & $39.4 \%$ \\
\hline & Adj.R & -6.1 & -3.1 & 0.8 & 0.3 & 2.5 & 7.8 & \\
\hline \multirow{3}{*}{ Worse } & row $\%$ & $29.3 \%$ & $34.1 \%$ & $8.5 \%$ & $3.7 \%$ & $11.0 \%$ & $13.4 \%$ & $100.0 \%$ \\
\hline & column $\%$ & & $8.0 \%$ & $7.0 \%$ & & & & $5.7 \%$ \\
\hline & Adj.R & -0.4 & 2.1 & 0.6 & -0.3 & -0.9 & -1.3 & \\
\hline \multirow{3}{*}{$\begin{array}{l}\text { The } \\
\text { same }\end{array}$} & row $\%$ & $37.4 \%$ & $26.8 \%$ & $6.3 \%$ & $4.9 \%$ & $12.3 \%$ & $12.3 \%$ & $100.0 \%$ \\
\hline & column $\%$ & $48.3 \%$ & $44.0 \%$ & $36.0 \%$ & $45.9 \%$ & $34.6 \%$ & $26.3 \%$ & $40.2 \%$ \\
\hline & Adj.R & 4.2 & 1.7 & -0.9 & 0.9 & -1.8 & -5.2 & \\
\hline \multirow{3}{*}{$\begin{array}{l}\text { I do } \\
\text { not } \\
\text { know }\end{array}$} & row $\%$ & $39.5 \%$ & $26.2 \%$ & $6.7 \%$ & $2.4 \%$ & $13.3 \%$ & $11.9 \%$ & $100.0 \%$ \\
\hline & column \% & $18.7 \%$ & $15.7 \%$ & $14.0 \%$ & $8.2 \%$ & $13.7 \%$ & $9.3 \%$ & $14.7 \%$ \\
\hline & Adj.R & 2.9 & 0.6 & -0.2 & -1.5 & -0.4 & -2.8 & \\
\hline
\end{tabular}

Source: authors' own research, $2020 \mathrm{~N}=1447$

Table 11

Reliability of Hungarian food as a factor of age

\begin{tabular}{|c|c|c|c|c|c|c|c|c|}
\hline \multirow{2}{*}{\multicolumn{2}{|c|}{$\begin{array}{l}\text { Reliability of } \\
\text { Hungarian food } \\
\text { compared to normal } \\
\text { food }\end{array}$}} & \multicolumn{6}{|c|}{ Age groups } & \multirow{3}{*}{$\begin{array}{c}\text { SUM } \\
(\%) \\
100 \%\end{array}$} \\
\hline & & \multirow{2}{*}{\begin{tabular}{|c|}
$\begin{array}{c}16-20 \\
\text { year }\end{array}$ \\
$23.9 \%$ \\
\end{tabular}} & \multirow{2}{*}{$\begin{array}{c}\begin{array}{c}21-25 \\
\text { year }\end{array} \\
23.0 \%\end{array}$} & \multirow{2}{*}{$\begin{array}{l}\begin{array}{c}26-30 \\
\text { year }\end{array} \\
6.9 \%\end{array}$} & \multirow{2}{*}{\begin{tabular}{|r|}
$\begin{array}{c}\text { 31-35 } \\
\text { year }\end{array}$ \\
$4.9 \%$ \\
\end{tabular}} & \multirow{2}{*}{$\begin{array}{c}\begin{array}{c}36-40 \\
\text { year }\end{array} \\
14.4 \% \\
\end{array}$} & \multirow{2}{*}{\begin{tabular}{|c|}
$\begin{array}{c}\text { over } \\
\mathbf{4 5} \\
\text { year }\end{array}$ \\
$26.9 \%$ \\
\end{tabular}} & \\
\hline Better & row $\%$ & & & & & & & \\
\hline & column $\%$ & $28.8 \%$ & $35.1 \%$ & $37.0 \%$ & $42.6 \%$ & $37.6 \%$ & $53.3 \%$ & $37.4 \%$ \\
\hline & Adj.R & -4.5 & -1.0 & -0.1 & 0.9 & 0.1 & 6.0 & \\
\hline \multirow[t]{3}{*}{ Worse } & row $\%$ & $37.3 \%$ & $29.3 \%$ & $6.7 \%$ & $5.3 \%$ & $12.0 \%$ & $9.3 \%$ & $100 \%$ \\
\hline & column \% & $6.3 \%$ & $6.3 \%$ & $5.0 \%$ & $6.6 \%$ & $4.4 \%$ & $2.6 \%$ & $5.2 \%$ \\
\hline & Adj.R & 1.2 & 1.0 & -0.1 & 0.5 & -0.6 & -2.2 & \\
\hline \multirow{3}{*}{$\begin{array}{l}\text { The } \\
\text { same }\end{array}$} & row $\%$ & $35.0 \%$ & $26.0 \%$ & $7.0 \%$ & $4.3 \%$ & $13.9 \%$ & $13.9 \%$ & $100 \%$ \\
\hline & column $\%$ & $49.4 \%$ & $46.6 \%$ & $44.0 \%$ & $44.3 \%$ & $42.4 \%$ & $32.2 \%$ & $43.9 \%$ \\
\hline & Adj.R & 2.8 & 1.2 & 0.0 & 0.1 & -0.5 & -4.3 & \\
\hline \multirow{3}{*}{$\begin{array}{l}\text { I do not } \\
\text { know }\end{array}$} & row $\%$ & $35.8 \%$ & $21.8 \%$ & $7.3 \%$ & $2.1 \%$ & $16.6 \%$ & $16.6 \%$ & $100 \%$ \\
\hline & column $\%$ & $15.5 \%$ & $12.0 \%$ & $14.0 \%$ & $6.6 \%$ & $15.6 \%$ & $11.9 \%$ & $13.5 \%$ \\
\hline & Adj.R & 1.5 & -0.9 & 0.2 & -1.6 & 1.0 & -0.9 & \\
\hline \multicolumn{2}{|l|}{ SUM (N) } & 445 & 350 & 445 & 350 & 100 & 61 & 205 \\
\hline
\end{tabular}




\section{Conclusions and Recommendations}

As a conclusion of the research results, we could state that convenience factors increased, during food purchases and plays a more important role in the sample, than the price. The preference system of the Hungarian food purchase, shows a difference compared to the criteria of normal food purchases: The importance of the content values is more dominant as is the geographical origin and the fact that the food is made from Hungarian ingredients. However, the criterion of "cheapness" is pushed into the background when buying Hungarian food compared to general food (H1 has been confirmed).

We also examined how Hungarian respondents perceived Hungarian food compared to normal food. Based on the results, we found that a significant proportion of respondents $(40.2 \%)$, do not perceive a difference in quality and most of them (44\%), consider the two categories to be the same in terms of reliability.

Examining the motives for buying Hungarian food, we found that neither fashion nor following a pattern, within the family, characterizes the respondents.

Analyzing the correlation between the purchase of Hungarian food and age, in the light of the results, we were able to state that the proportion of Hungarian food in the consumer basket increases with the advancement of age (H2 / a). As we were able to prove statistically, that there is a correlation between age and the assessment of the reliability and quality of Hungarian food ( $\mathrm{H} 2$ / b confirmed). Typically, the respondents belonging to Generation X, considered Hungarian food to be better and more reliable, the respondents of Generation Z (16-25 years old), rated Hungarian food as of the same quality and reliability, or they could not typically make a judgment.

According to the results, it can be said that the customers of Hungarian food, normally come from the members of Generation X, so according to age, they form the main target group. These consumers typically have a mature system of preferences and sufficient financial resources. In the case of the younger respondents (Generation $\mathrm{Z}$ ), we could see many still insecure customers, the immaturity of their preference system, may be one of the main reasons why they do not statistically prefer Hungarian foods. Just as buying them is not considered a fashion pursuit, this trend would be worthwhile changing, knowing the values of a given generation. After all, trendy pattern-following, is dominant in their case, they are also looking for reference persons, samples, role models.

In our opinion, a communication campaign aimed at young people and involving them, could do a lot to promote Hungarian foods, among Generation Z. This can also be an important aspect, because the members of this generation, may soon represent a potential, solvent target group, with an independent income. In this form, they could play a significant role among Hungarian food consumers, in the future. 


\section{References}

[1] Verlegh P.W.-Steenkamp J. (1999): A Review and Meta-Analysis of Country of Origin Research. Journal of Economy Psychology, Vol. 20. pp. 521-546

[2] Malota E. (2003): Consumer ethnocentrism. The effect of stereotypes, ethnocentrism and image of national origin on the perception of domestic and foreign products. Fogyasztói etnocentrizmus. A sztereotípiák, az etnocentrizmus és az országeredet-imázs hatása a hazai és a külföldi termékek megítélésére. PhD-értekezés, Budapesti Közgazdaságtudományi és Államigazgatási Egyetem

[3] Javalagi, G. R., Khare, P. V., Gross, C. A., \& Scherer, F. R. (2005): An application of consumer ethnocentrism model to French consumers, International Business Review 14 (2005), pp. 325-344

[4] Khan, S. S., Yang, Y., Greaney, T., \& Leung, P. (2020): Who Leads the Price in Honolulu's Food Market? An Evaluation of the Competitiveness of Local Foods, Journal of International Food \& Agribusiness Marketing, 32 (5), pp. 464-481

[5] Sharma, S., Shimp, T. A., \& Shin, J. (1995): Consumer Ethnocentrism: A Test of Antecedents and Moderators, Journal of the Academy of Marketing Science, 23 (1) pp. 26-37

[6] Klein, J. G., Ettenso, N. R., \& Morris M. D. (1998) The animosity model of foreign product purchase: An empirical test in the people's Republic of China, Journal of Marketing, 62(1), pp. 89-101

[7] Shankarmahesh, M. N. (2006): Consumer ethnocentrism: an integrative review of its antecedents and consequences. International Marketing Review, Vol. 23, No. 2, pp. 146-172

[8] Wang, C., \& Chen, Z. (2004): Consumer ethnocentrism and willingness to buy domestic products in a developing country setting: Testing moderating effect, Journal of Consumer Marketing, 21 (6), pp. 391-400

[9] Ittersum K. (2002): The role of region of origin in consumer decisionmaking and choice. PhD. dissertation, Mansholt Graduate School, Wageningen, Hollandia, 2002

[10] Szakály Z., Szigeti O., Szente V., Polereczki Zs. (2008): Analysis of consumer habits and attitudes in the traditional Hungarian food market. Fogyasztói szokások és attitüdök elemzése a hagyományos magyar élelmiszerek piacán. Kutatási tanulmány I-IV. Research Study I-IV. Budapest-Kaposvár

[11] Chaney D. (1996): Lifestylies, London: Routledge 
[12] Ilbery B., Kneafsey M. (1999): Niche markets and regional specialty food products in Europe: towards a research agenda, environment and Planning. 31, pp. 2207-2222

[13] Csatáriné Dogi, I. (2015): Fogyasztói etnocentrizmust befolyásoló tényezők vizsgálata -szakirodalmi áttekintés Analysis of affecting factors of consumer ethnocentrism a literature review Journal of Central European Green Innovation 3 (3), pp. 37-44

[14] Németh, K., Birkner, Z., Katona, A., Göllény-Kovác, N., Bai, A., Balogh, P., Gabnai, Z., \& Peter, E. (2018): Can Energy be a "Local Product" Again? Hungarian Case Study, Sustainability 2020, 12(3), 1118

[15] Berács, J., Malota, E. (2000): Fogyasztói etnocentrizmus, - az etnocentrizmus és az országeredet imázs kapcsolata a termékválasztásban. Consumer ethnocentrism, - the relationship between ethnocentrism and country image in product choice. Marketing \& Menedzsment, 2000/2

[16] Szakály Z., Pallódé Kisérdi I., Nábrádi A. (szerk.) (2010): Marketing in the traditional and regional food market. Marketing a hagyományos és tájjellegü élelmiszerek piacán. Kaposvári Egyetem, Kaposvar University, 2010

[17] Popovics A. (2009): The possible role of geographical and traditional Hungarian products in food consumer behavior. A földrajzi helyhez kapcsolódó és a hagyományos magyar termékek lehetséges szerepe az élelmiszerfogyasztói magatartásban. PhD értekezés, $\mathrm{PhD}$ dissertation, Szent István Egyetem, Gödöllő

[18] Medián (2009): Should it be cheap or Hungarian? Olcsó legyen vagy magyar? - http://www.median.hu/printcikk.ivy?artid=7e7a6d29-ceb0-477db29a-3195f172ae15 (2019.09.01.)

[19] Garai-Fodor M., Csiszárik-Kocsir Á. (2018): Validity of value-based consumer behavior models in the financial awareness of Generations $Z$ and $Y$. Értékrend alapú fogyasztói magatartásmodellek érvényessége a Z- és Y generáció pénzügyi tudatossága terén. Pénzügyi Szemle 2018/4, pp. 518536

[20] Töröcsik M. (2017): Consumer Behavior - Insight, Trends, Customers. Fogyasztói magatartás - Insight, trendek, vásárlók. Akadémiai Kiadó, p. 225

[21] KPMG Tanácsadó Kft. (2018): Consumer Drivers - What Drives a Versatile Consumer? Fogyasztói mozgatóerők - Mi irányítja a sokoldalú fogyasztót? Kutatási tanulmány, https://home.kpmg/content/dam/kpmg/hu/ pdf/KPMG_Fogyasztoi_mozgatoerok.pdf (2019.09.01.)

[22] Varga E. (2013): Living Generation Z and Promotion - Is Rewarding Expected? A $\mathrm{Z}$ generáció és a promóció megélése - elvárás a jutalmazás? OTDK dolgozat, 2013, pp. 29-53 
[23] Pál E. (2013): About the $Z$ generation. A Z-generációról. Pécsi Tudományegyetem, 2013, pp. 11-15

[24] Malhotra Naresh, K., Simon J. (2017): Marketingresearch, Marketingkutatás, Akadémiai Kiadó

[25] Horváth Á., Fürediné Kovács A., \& Fodor M. (2005): The effect of values on nutrition $\mathrm{Az}$ értékrend hatása a táplálkozásra (In: Élelmiszer, táplálkozás, marketing, II. évf. (1-2)

[26] Horváth, A. (1996): A fogyasztói magatartás és az élelmiszerfogyasztás jellemzői. Characteristics of consumer behavior and food consumption. $(\mathrm{PhD})$ Doktori értekezés, Doctoral Dissertation, GATE, Gödöllö

[27] Auruskeviciene, V., Vianelli, D., \& Reardon, J. (2012): Comparison of consumer ethnocentrism. Transformations in Business \& Economics, Vol. 11, No. 2, pp. 20-35

[28] Han, C. M. (1988): The role of consumer patriotism in the choice of domestic versus foreign products, Journal of Advertising Research, 1988, $3(1)$, pp. 25-32

[29] Liu, L., \& Orth, U. (2021): Cultural Differences in Design-Based Product Evaluation: The Role of Holistic and Analytic Thinking, Sustainability, Vol. 13,2775

[30] Gauthier, D. (1986): Morals by Agreement Clarendon Press Oxford In: S. Nagy, K. (szerk.) (2008): Értékek és Normák interdiszciplináris megközelítésben Values and Norms in an interdisciplinary approach Budapest: Gondolat Kiadó, 223 p.

[31] Hawkins, D.-Best R.-Coney K. (1992): Consumer Behavior $5^{\text {th }}$ ed. Irwin, Boston M. A. In: Hofmeister-Tóth Á. (2003): Fogyasztói magatartás, Consumer behaviour Budapest: Aula Kiadó, 325 p.

[31] Sajtos L., \& Mitev A. (2007): SPSS kutatási és adatelemzési kézikönyv, SPSS Research and Data Analysis Manual Budapest: Alinea Kiadó 